\title{
Food practices associated with increased risk of bacterial food-borne disease of female students in self-catering residences at the Cape Peninsula University of Technology
}

\author{
Linda du Toit and Irma Venter
}

\begin{abstract}
OPSOMMING
Kommer is oor die voedselpraktyke van studente in koshuise van die Kaapse Skiereilandse Universiteit van Tegnologie: Kaapstad-kampus, uitgespreek nadat daar tot die selfvoorsiening van voedsel oorgeskakel is. Gestruktureerde onderhoude is met 60 ewekansig geselekteerde swart vroulike studente in die selfspysenieringkoshuise gevoer. Die doel was om vas te stel of hul praktyke rakende die aankope, berging, bereiding en gaarmaak van voedsel, asook die hantering van voedsel wat na maaltye oorbly, met riglyne om bakteriële voedseloordraagbare siektes te voorkom, ooreenstem. Die resultate toon dat die studente sommige veilige voedselaankoperiglyne volg en dat hulle in baie gevalle bestanddele en voedsel wat na ' $n$ maaltyd oorbly, veilig berg. In teenstelling is persoonlike higiëne, bv. die was van hande met seep en water, en algemene higiëne, bv. vermyding van kruiskontaminasie tussen rou en gereed-om-te-eet voedselitems, afgeskeep. Die studente het verder aangedui dat hulle voedselitems genoegsaam gaarmaak, maar voedsel wat vooraf berei word of na maaltye oorbly, is nie voldoende verhit nie. Minder as die helfte van dié studente was bewus van die oorsake van voedseloordraagbare siektes, hoë risiko voedselitems en kruiskontaminasie, terwyl nog minder studente aangedui het dat hulle die ooreenstemmende veilige voedselpraktyke in die verband, uitvoer. Studente wat bewus was van die verband tussen pluimvee en Salmonella of in staat was om kruiskontaminasie te defineer was nie meer geneig om voedselpraktyke, wat bakteriële voedseloordraagbare siektes sal voorkom, te rapporteer, as dié wat nie daarvan bewus was nie. Daar word aanbeveel dat ' $n$ intervensie program spesifiek gemik op die verbetering van vroulike studente in selfspysenieringkoshuise se voedselpraktyke opgestel en geïmplementeer word om bakteriële voedseloordraagbare siektes te voorkom.
\end{abstract}

\section{- Ms LD du Toit}

Department of Food and Agricultural Sciences Cape Peninsula University of Technology

\section{- Mrs I Venter}

Department of Food and Agricultural Sciences Cape Peninsula University of Technology

CPUT is acknowledged for providing financial assistance for this research. The authors would like to thank Mrs R Krause for statistical processing of data.

\section{INTRODUCTION}

In the range of 6.5 million (Altekruse et al, 1999) to 76 million (Mead et al, 1999) food-borne disease cases are recorded annually in the United States of America (USA). The most common food-related illnesses result from bacterial food infections and intoxications (Jones, 1992:107; Brown, 2000:114, Crawford \& Murano, 2002; Bennion \& Scheule, 2004:67). Bacterial foodborne infections are caused by the proliferation of micro-organisms, such as Salmonella and Campylobacter jejuni in the intestine of the host, whereas bacterial food-borne intoxications result from toxins produced by bacteria such as Staphylococcus aureus and Clostridium botulinium (Jones, 1992:109; Pelczar et al, 1993:680).

Food-borne disease can only be prevented by the multifaceted efforts of all role players involved in the production, processing, regulation and preparation of food (Bennion \& Scheule, 2004:57). Epidemiological data from Europe, the USA, the United Kingdom (UK), Australia and New Zealand indicate that a considerable proportion of food-borne disease cases are caused by food prepared in the home (Williamson et al, 1992; Worsfold \& Griffith, 1997b; Miles et al, 1999; Meredith et al, 2001). By not adhering to bacterial food-borne disease prevention guidelines consumers can undo the efforts made by food producers to provide safe food (Simpson, 1993). Factors that contribute to outbreaks of bacterial food-borne disease in homes include, obtaining food from unsafe sources; contaminated raw food items; improper food storage; poor personal hygiene during food preparation; inadequate cleaning of kitchen equipment and utensils; inadequate cooking; inadequate cooling and reheating of food items and a prolonged time lapse between preparing and consuming food items (Bryan, 1988; Bean \& Griffen, 1990; Pelczar et al, 1993:680; Knabel, 1995).

Other factors that appear to influence the prevalence of bacterial food-borne disease, resulting from food prepared in domestic kitchens, are age, how frequently the consumer prepares food, and whether the kitchen is shared. In studies conducted in the USA Klontz et al (1995) found that young adults did not adequately clean chopping boards, used for raw and ready-to-eat foods, as often as older adults, while Altekruse et al (1996) found that young adults and occasional food preparers, described as people who prepare the main meal only some of the time, were more 
likely not to wash their hands or take precautions to prevent cross-contamination when preparing meals. The risk of bacterial food-borne disease also increases when food is prepared in communal kitchens, as in student accommodation, youth hostels and shared homes. This increase may be due to the number of individuals using the kitchens, the lack of feelings of responsibility and the differing standards of hygiene of the users of these kitchens (Sharp \& Walker, 2003).

Since 2002 the majority of the student residences housing undergraduate students of the Cape Peninsula University of Technology (CPUT): Cape Town campus, have a self-catering food provision system. A catering company was previously contracted to supply meals to the students in the residences. The catering company staff prepared the meals, in centrally located kitchens, under supervision, and in accordance with food-borne disease prevention guidelines as set out by the catering company. Students in the residences were generally not involved in the purchasing, storage or preparation of food items for meals. The change in catering arrangements was necessitated by a lack of finances on the part of the students to pay for the fullboard accommodation.

Although the majority of consumers in studies conducted in the USA and Australia reported an awareness of some food-borne bacterial pathogens, such as Salmonella, they lacked awareness of other pathogens, such as Staphylococcus aureus, Listeria monocytogenes and Escherichia coli (Williamson et al, 1992; Jay et al, 1999a). Williamson et al (1992) also found in their study conducted in the USA that consumers under 35 years of age knew less about the causes of bacterial food-borne disease than those over 35 years of age. Consumer awareness of the causes of bacterial food-borne disease had a positive effect on their self-reported adherence to food-borne disease prevention guidelines (Altekruse et al, 1996; Meer \& Misner, 2000; Lin et al, 2004). In studies conducted by the Canadian Food Inspection Agency (1998), Griffith and Redmond (2001) and Clayton et al (2003) a large number of consumers (47\% to $85 \%$ ) reported following bacterial food-borne disease prevention guidelines, such as washing their hands after handling raw food items. However, in other studies, conducted in Australia, the USA and the UK there were significant gaps in the self-reported adherence by consumers to some of the bacterial food-borne disease prevention guidelines (Jay et al, 1999a; Knabel, 1995).

Only two published studies that investigated highereducation students' awareness of bacterial food-borne disease (Unklesbay et al, 1998) and the adherence to guidelines that would prevent food-borne disease (Unklesbay et al, 1998; Sharp \& Walker, 2003) could be obtained. The student respondent groups resided in the USA and the UK respectively. Very little is known about the awareness of South African consumers regarding the causes of bacterial food-borne disease and their adherence to guidelines that would prevent the occurrence of food-borne disease. A
South African study on young adults preparing food in communal kitchens was prompted as a result.

The objectives of this study were to determine whether female students living in the self-catering residences of the CPUT: Cape Town campus were: (i) aware of selected aspects of food-borne disease and (ii) reported adhering to guidelines that would prevent bacterial food-borne disease, when purchasing, storing, preparing, cooking and handling left-over food items intended for their own consumption. In addition the relationship between the awareness of food-borne disease and the self-reported adherence to guidelines that would prevent bacterial food-borne disease was investigated.

\section{LITERATURE REVIEW}

\section{Food preparation practices associated with bacterial food-borne disease}

Food preparation, whether in a domestic or communal kitchen, includes the purchase and transport of ingredients to the kitchen and the storage of ingredients in frozen, chilled or dry storage areas. It further includes preparation actions such as measuring, cleaning, and peeling, slicing, chopping, and mixing of ingredients in the creation of dishes. The final steps include the cooking and service of these dishes. Where food items are cooked in advance of consumption, or left over after consumption, actions such as the storage and, where applicable reheating before service are included (Griffith \& Worsfold, 1994). According to Bryan (1988), Bean and Griffen (1990), Pelczar et al (1993:680) and Knabel (1995) each one of these actions can contribute to outbreaks of bacterial foodborne disease.

Purchasing Food items are purchased from supermarkets, fast-food outlets and street vendors (OpareObisaw, 1998; Azanza, 2001; Nel \& Steyn, 2001). Studies in developing countries, such as South Africa and Ghana, show that street vendors do not always follow bacterial food-borne disease prevention guidelines. Despite this, the microbial levels of most of the street foods investigated in the studies conducted in Johannesburg, South Africa and Accra, Ghana, were within acceptable limits (Mosupye \& Von Holy, 2000; Kubheka et al, 2001; Mensah et al, 2002). However, in a study conducted by the Department of Health in the Western Cape in 1995, food items obtained from street vendors in tourist areas carried high concentrations of Escherichia Coli and Staphylococcus Aureus (Sidley, 1995).

In addition to purchasing food items from reputable dealers, certain food items such meat, poultry, eggs, fish, dairy products and combination-type chilled foods, such as tuna salad, should be chosen and handled with extra care. These food items, high in protein and water, are at risk of bacterial contamination and, due to their composition, ideal to support bacterial growth (Brown, 2000:129). Van Nierop et al (2005) found that $60 \%$ of whole-chicken carcasses, sourced 
from various retailers in Gauteng, were contaminated with Campylobacter spp. (32.3\%), Salmonella spp. $(19,2 \%)$ or Listeria Monocytogenes $(19,2 \%)$. Moore et al (2002) found an even higher number of contaminated carcasses in a study conducted in Northern Ireland, where $94 \%$ of the fresh and $77 \%$ of the frozen chickens obtained were contaminated with Campylobacter spp. In addition Harrison et al (2001) found in a study conducted in South Wales, UK that 34\% of whole-chicken packaging was contaminated with Campylobacter and $11 \%$ with Salmonella. Other highrisk raw food items include minced meat and shellfish. Although the carcass of a healthy animal usually has a low level of surface microbial contamination, the chopping or grinding of the meat allows for a high potential of bacterial contamination (Pelczar et al, 1993:846). Raw shellfish from polluted water may be contaminated with Escherichia coli (Roberts, 1990). In recent years, bacterial food-borne disease has also been associated with foods that do not fit into the high protein/high water risk category (Brown, 2000:129). Fresh fruit and vegetables may be contaminated with Listeria monocytogenes, Clostridium botulinium and Bacillus cereus, which are present in the soil in which they are grown (Roberts, 1990; Adams \& Moss, 1995:176; Kubheka et al, 2001). Contamination with organisms, such as Salmonella, Escherichia coli 0157:h7, Campylobacter jejeni and Vibrio cholerae, can also occur owing to the use of contaminated wash-water used for partially prepared fresh vegetable products (Adams \& Moss, 1995:186; Beuchat \& Ryu, 1997).

Once purchased food items need to be transported to the kitchen for further preparation. High-risk food items, such as raw meat and poultry, are usually purchased in a chilled or frozen state. If these low temperatures are to be maintained, transport time should be as brief as possible and the items transported in an insulated cool bag. In this way the growth of pathogenic, spoilage bacteria can be limited (Griffith \& Worsfold, 1994; Jay et al, 1999a).

Storage On reaching the kitchen, food items should be stored and handled correctly to decrease the growth of the micro-organisms already present and to minimise the risk of contamination (Griffith \& Worsfold, 1994; Gorman et al, 2002). Results from studies conducted in the UK and Australia indicate that many consumers do not follow bacterial foodborne disease prevention guidelines, such as keeping high-risk food products at or below $4^{\circ} \mathrm{C}$, separating raw and ready-to-eat food products during storage, or applying the correct procedures when thawing frozen food items (Worsfold \& Griffith, 1997b; Jay et al, 1999a). Most consumers are aware that a refrigerator extends the shelf life of food items and keeps food safe. However, in order to attain these beneficial effects and to prevent the growth of Staphylococcus aureus, Clostridium perfringens, Listeria monocytogenes and Bacillus cereus, a refrigerator must be operated correctly to maintain a temperature of below 5 ${ }^{0} \mathrm{C}$ (Jay et al, 1999a; Medeiros et al, 2001a; Brown, 2000:130; Rosset, 2001). Storing raw meat, poultry or fish on the top shelf in the refrigerator increases the risk of cross-contamination due to the potential dripping of raw juices onto other foods stored beneath. The risk is especially high if the foods stored below are ready-to-eat items that will not be heated to high enough temperatures to destroy pathogenic bacteria (Chicken safety tips, 2001; Bennion \& Scheule, 2004:63). Frozen meat and poultry should be thawed by putting it in the refrigerator, placing it in a sealed package in cold water or in a microwave oven. Defrosting frozen food items at room temperature or in warm water is a hazardous practice as temperatures between $5^{\circ} \mathrm{C}$ and $60^{\circ} \mathrm{C}$ can lead to the growth of foodborne pathogens (Handling food in the home, 2000; The big thaw. Safe defrosting methods for consumers, 2003).

\section{Preparation}

Personal hygiene during preparation When hands are not washed correctly and at appropriate times, pathogens such as Escherichia coli O157: H7 can be transmitted to prepared or ready-to-eat food items (Collins 1997; Medeiros et al, 2001a), directly to the mouth, or to other household members (Jay et al, 1999b). Patrick et al (1997) and Hunter (2000) found that drying of hands after washing is critical as bacteria are frequently recovered from hands that have not been dried effectively. The residual moisture remaining on hands, if not dried, contributes to the number of micro-organisms transferred from hands to solid surfaces. The choice of cloth for the drying of hands is important. Using a kitchen cloth to dry hands may lead to recontamination as such a cloth is normally used for actions such as wiping surfaces. Using a drying cloth is also not recommended as it is possible that following hand-washing and even more so if the hands are merely rinsed, bacteria will be transferred from the hands to the cloth. In addition, the damp state of many kitchen and drying cloths creates conditions for the survival of bacteria over a significant time period. If subsequently used for drying dishes or wiping hands, re-contamination would occur (Meredith et al, 2001; Bennion \& Scheule, 2004:62).

General hygiene during preparation Bacterial contamination in the kitchen often occurs during processing of raw foods (Enriquez et al, 1997). Raw meat and poultry products may be contaminated with Salmonella typhimurium DT105, Campylobacter, Listeria monocytogenes and Escherichia coli 0157: $\mathrm{H} 7$ (Ralston et al, 2000; Zhao et al, 2001; Borch \& Arinder, 2003). During food preparation pathogenic organisms may be transferred to food items by the handler both directly or by cross-contamination through hands, surfaces, utensils and equipment that have been inadequately cleaned and disinfected between the preparation of different types of food (Roberts, 1990; Scott \& Bloomfield, 1990). In studies conducted by De Wit et al (1978), Gorman et al (2002), Mattick et al (2003) and Haysom and Sharp (2004) pathogenic micro-organisms were spread from raw chickens to hand and contact surfaces in kitchens during the domestic preparation of meals. 
Cooking and serving The consumption of highrisk food products, such as contaminated raw or undercooked protein foods, can contribute to outbreaks of bacterial food-borne disease (Bryan, 1988; Roberts, 1990; Jones, 1992:112; Doyle, 1993, Griffith \& Worsfold, 1994; Adams \& Moss, 1995:186). It is thus recommended that all high-risk food items be cooked to a temperature of at least $74^{\circ} \mathrm{C}$ (Brown, 2000:129; Bennion \& Scheule, 2004:64). Food items should be served as soon as possible after preparation. If food items are kept for extended periods, they must be kept either above $60{ }^{\circ} \mathrm{C}$ or below $5^{\circ} \mathrm{C}$ (Brown, 2000:130). Food items prepared in advance of consumption should be rapidly cooled, within 90 minutes, and stored covered, below $5{ }^{\circ} \mathrm{C}$ for less than three days (Griffith \& Worsfold, 1994).

Handling left-over food The handling of left-over foods is a further high-risk action in a domestic kitchen (Beumer and Kusumaningrum, 2003). Brinkman et al (1999:12) found that 7,3\% of the left-over food samples collected from domestic kitchens showed high bacterial counts $\left(>10^{6} \mathrm{cfu} / \mathrm{g}\right)$. Bacteria found in these samples included Enterobacteriaceae and Bacillus cereus. The microbiological guideline for ready-to-eat foods, such as cooked and sliced chicken, as indicated by the Airline Catering: Code of Good Catering practice in Britain is $<10^{3} \mathrm{cfu} / \mathrm{g}$ (as cited by Worsfold \& Griffith, 1995). Beumer and Kusumaningrum (2003) concluded that leftovers should be handled hygienically, kept in clean containers and cooled as quickly as possible. Leaving food to cool at room temperature before refrigeration allows for an uncontrolled time period where food is left in the temperature danger zone of $5{ }^{\circ} \mathrm{C}$ to $60^{\circ} \mathrm{C}$ (Knabel, 1995; Brown, 2000:130). According to Brown (2000:130), improper cooling of prepared food items frequently contributes to outbreaks of food-borne disease. When reheating previously cooked foods, the same high temperatures should be reached as in the initial cooking as poor storage practices may have led to the proliferation of large numbers of bacteria in the cooked food (Worsfold, 1995).

\section{Bacterial food-borne disease awareness related to food practices associated with decreased risk of bacterial food-borne disease}

In studies conducted in the USA by Altekruse et al (1996), Meer and Misner (2000) and Lin et al (2004), it was established that the self-reported awareness of guidelines to prevent bacterial food-borne disease had a positive effect on the self-reported food practices associated with a decreased risk of food-borne disease. Altekruse et al (1996) found that respondents who were able to specify a food item associated with Salmonella spp. were more likely to report washing their hands and cutting boards after handling raw meat or poultry, than those respondents who were unaware of this association. Similarly, Lin et al (2004) found that the self-reported awareness of Salmonella was associated with safer before-meal preparation hand-washing practices and that the awareness of Campylobacter or Escherichia coli was associated with serving thoroughly cooked hamburgers.
However, in other studies where respondents reported their own home food preparation practices, awareness of the causes of microbial food-borne disease did not always correspond with practices associated with a decreased risk of food-borne disease. Williamson et al (1992) reported that $51 \%$ of the respondents correctly identified Salmonella as a term associated with poultry and eggs and indicated that they would use the correct procedure of immediately refrigerating a chicken after cooking. In contrast, $15 \%$ of the respondents did not know the term, but indicated using the correct storage procedure, and $23 \%$ of the respondents, although they correctly identified the term, did not indicate following proper storage procedures for cooked chicken.

Lack of awareness may thus contribute to foodhandling practices that increase the risk of bacterial food-borne disease, but ignorance may not be the only cause why consumers may fail to apply principles already known to them (Worsfold \& Griffith, 1997a). Williamson et al (1992) concluded that knowledge in itself did not guarantee that bacterial food-borne disease prevention practices would be implemented.

\section{METHODOLOGY}

\section{Sample}

During June 2003 the total number of students studying at the Cape Technikon (now the Cape Town campus of the CPUT) was 15 592, of whom 7991 were female and 812 resided in the self-catering residences (Student statistics, 2003) (See Table 1). Stratified random sampling was used to obtain a sample of $60 \mathrm{fe}-$ male students from the self-catering residences. The kitchens in each residence were numbered and a list compiled of the students who used a particular kitchen. Simple random sampling, using a table of one-, two- and three-digit random numbers (Mason \& Bramble, 1989:431), was then used to determine the specific participants from each name list of kitchen users. The use of kitchens is allocated by the residential management and is based on the location of a student's room. All kitchens are supplied with basic equipment such as a stove, microwave oven, toaster and kettle by the institution (Residence facilities, 2003), but differ in size, layout and additional equipment. To decrease the effect of the kitchen environment on food preparation practices, the sample was drawn so that most of the kitchens were represented in the study. As indicated in Table 1 the student representation in the sample equalled the student ratio to specific residences.

The study population was limited to female students living in the self-catering residences, with the exception of female students studying the National Diploma (ND): Consumer Science: Food and Nutrition, as they were either involved in the preliminary study, the pretesting of the questionnaire or participated as interviewers. Permission to undertake the study was granted by the Head of the Department of Residences and the wardens of the self-catering residences. 
TABLE 1: $\quad$ DISTRIBUTION OF STUDENTS AND RESPONDENTS PER SELF-CATERING RESIDENCE

\begin{tabular}{|c|c|c|c|c|c|}
\hline \multirow{2}{*}{$\begin{array}{c}\text { Cape Peninsula University of } \\
\text { Technology: Cape Town } \\
\text { campus self- catering } \\
\text { residences }\end{array}$} & \multicolumn{2}{|c|}{$\begin{array}{c}\text { Female students } \\
\text { per residence }\end{array}$} & \multirow{2}{*}{$\begin{array}{c}\text { Kitchens per } \\
\text { residence }\end{array}$} & \multicolumn{2}{|c|}{$\begin{array}{l}\text { Respondents per } \\
\text { residence }\end{array}$} \\
\hline & $\mathbf{n}$ & $\%$ & & $\mathbf{n}$ & $\%$ \\
\hline Catsville Residence & 432 & 53,2 & 18 & 31 & 51,7 \\
\hline Elizabeth Women's Residence & 236 & 29,1 & 11 & 18 & 30,0 \\
\hline DownTown Lodge & 78 & 9,6 & 7 & 6 & 10,0 \\
\hline Waterside Residence & 50 & 6,2 & 1 & 4 & 6,7 \\
\hline J\&B House & 16 & 2,0 & 5 & 1 & 1,7 \\
\hline Total & 812 & 100 & 42 & 60 & 100 \\
\hline
\end{tabular}

\section{Questionnaire development and testing}

Development During October 2002 a preliminary study was undertaken to collect information that could serve as a starting point in constructing a questionnaire covering the adherence to bacterial food-borne disease prevention guidelines by female students in self-catering residences. A structured questionnaire with closed-ended questions on the ingredients purchased, the preparation of meals, the availability of food preparation equipment/utensils and the kitchencleaning practices in the female self-catering residences was distributed to $30 \mathrm{ND}$ : Consumer Science: Food and Nutrition students residing in the selfcatering residences. Nineteen students returned the questionnaires. The results of the questionnaire indicated that more than half (58\% to $84 \%$ ) of the students purchased ingredients such as maize porridge, bread, milk, cheese, polony, rice, dried pasta, breakfast cereals, raw and frozen vegetables and raw chicken. These ingredients were used in the preparation of breakfast and supper for themselves. Students also indicated that they had the necessary equipment and utensils available for food preparation. However, kitchen-cleaning practices differed according to the specific residence and were not included in the final questionnaire and the study.

As there is no standard for measuring adherence to bacterial food-borne disease prevention guidelines in the home (Worsfold \& Griffith, 1997a; Lewis, 1998), the data gathered from the preliminary study, together with the following sources, were used for the compilation of five bacterial food-borne disease prevention guidelines that were applicable to the objectives of this study. The sources are as follows:

- The South African regulations relating to food premises and the transport of food (South Africa. Department of Health, 1977).

- The food handling concepts identified by Medeiros et al (2001b) based on the food items mostly associated with pathogens causing food-borne illness and the unsafe food-handling behaviours most often practised by food handlers.

- The critical control points identified by Griffith and Worsfold (1994) in applying Hazard Analysis and Critical Control Point (HACCP) principles to domestic food preparation.
Each of the five guidelines was used as a starting point for formulating individual close-ended questions on the usual behaviour of the respondents with "usual" defined as "most of the time". Each of the questions had between two and four possible response categories. Response categories were supplied to the respondents as possible answers during the interviews. To overcome the problem of excluding a response category, a category labelled "other" was added. Responses interpreted by the interviewers as "unsure" were also indicated in the "other" options. The utilisation of mostly close-ended response categories, providing a number of options, made for greater uniformity of responses.

The guideline "follow safe purchasing practices" led to three questions. The first two pertained to the place where ingredients and ready-to-eat food items were usually purchased and the last the purchasing characteristics taken into consideration when purchasing food items. The guideline "store ingredients safely" led to questions on when, where, how and for how long ingredients were stored. The handling of frozen food items was also included under this guideline. The guideline "practise good personal and general hygiene during preparation" led to questions on the washing and drying of hands before and during food preparation as well as the cleaning of fresh produce, utensils and equipment during food preparation. The guideline "cook food items thoroughly" concentrated on the cooking of high-risk food items such as chicken and burger patties. The final guideline "handle leftovers safely" contained questions on the storage and reheating of left over food and the storage and reheating of food prepared in advance. A total of 38 questions were formulated to address adherence to the five selected bacterial food-borne disease prevention guidelines.

According to Jones (1992:112) and Pelczar et al (1993:687) Salmonella is one of the major causes of food-borne disease and its incidence is increasing. In studies conducted in the USA and Australia a larger number of consumers (80\% to $96 \%)$ were aware of Salmonella compared to an awareness of other foodborne bacteria (3\% to 74\%) (Altekruse et al, 1996; Jay et al, 1999a). In addition, more than half of these consumers were also aware of the link between Salmonella and poultry. Based on these results and the questions used by Williamson et al, (1992), Altekruse 
et al (1996) and Jay et al, (1999a) four additional questions were formulated to determine consumer awareness of food-borne disease and food-borne pathogens. These four open-ended questions focused on the causes of food-borne disease, specific bacteria associated with food-borne disease, the association between Salmonella and certain food items or preparation practices and the meaning of the term "crosscontamination. During the interview respondents were not supplied with answers to these factual questions. A "don't know" option was included as a potential response. Babbie (1990:128) and Bowling (2002:279) recommend the inclusion of such an option as it lowers the risk of obtaining incorrect information by forced choice.

In the section on biographical information interviewers noted gender and race. In addition respondents were asked their age, the course they were studying and whether they received information on bacterial foodborne disease prevention guidelines at school or as part of a subject they were studying at the CPUT. This section included a total of 5 close-ended questions with two to six response options.

Testing A pre-testing of the questionnaire was conducted to eliminate any misunderstandings and ambiguities caused by improper wording of questions and to detect possible flaws in the planned methodology (Babbie, 1990:221; Huysamen, 1994:197). It was noted whether participants found questions understandable and unambiguous and whether some questions were answered in an unexpected manner (Babbie, 1990:230). Nine ND: Consumer Science: Food and Nutrition students residing in self-catering residences took part in the pre-test. The procedure to be used during the interview was used, but the students were not supplied with the possible answers to the closed-ended questions. The students indicated that three of the questions on bacterial food-borne disease prevention practices were not entirely clear. Examples of food items were added to the wording of these questions. In two of the questions additional responses were added. None of these students were familiar with the term "food-borne disease". When the term was explained, the students indicated that they would use the word "food poisoning". The term "food poisoning", although not the correct terminology, was used in the questionnaire.

\section{Interviewers}

Ten ND: Consumer Science: Food and Nutrition students, of the same gender, race and background as the respondents, were trained as interviewers. This similarity enabled the interviewers to be familiar with the cultural influences and food habits of the respondents. In addition, the interviewers all lived in the residences, making them familiar with the daily routine of residence occupants. Furthermore, these students had knowledge of food items and preparation practices as it formed part of their course content. The interviewers participated in a one-day training session. Interviewers were trained as a group to ensure that they all received the same information. Role-playing was used as the main training technique.

\section{Validity and reliability}

The questionnaire was compiled based on the results of the preliminary study as well as food safety guidelines selected from recognised sources. Face and content validity was subjectively judged during the construction of the initial questionnaire. The researchers, four staff members in the Faculty of Applied Sciences: CPUT and a statistician reviewed the items in the questionnaire for wording, clarity and relevance.

The questionnaire was tested on a convenient sample of female students from self-catering residences. The nine students making up the sample were all studying the ND: Consumer Science: Food and Nutrition programme, which would make them more knowledgeable about the content of the questionnaire, compared to the general population, as the prevention of foodborne disease and food preparation formed part of their course content. This could have influenced their understanding of the questions. However, they were able to provide valuable feedback on the questionnaire due to their basic knowledge of food preparation as well as their familiarity with the food preparation practices in the self-catering residences.

Social desirability bias is associated with an interview situation (Bowling, 2002:153). Social desirability bias may influence the respondents making them feel the need to create a good impression. However, the use of fellow students as interviewers compared with interviewers formally qualified in food science and/or nutrition may have a lesser effect on the expectations felt by the respondents towards the interviewers on following food practices that are in line with bacterial foodborne disease prevention guidelines.

The reliability of the questionnaire as such was determined on a limited basis. The structured response format of the questionnaire, made possible by the preliminary study, the pre-testing of the study and the training of the interviewers, as well as the fact that the interviewers were knowledgeable in the fields of the research study, support the inter-interviewer reliability testing done that did yield identical results.

\section{Data collection}

The interviews took place during the first three weeks of May 2003 at the residences. By May, even first year students should have settled in as they would have been living in the residence for approximately three months and should have developed a routine regarding their food practices. The first semester examinations commence at the beginning of June and food practices might change during this time. It was assumed that the small sample would, to a certain extent, cover the characteristics of the population. However, owing to the small sample, the results obtained cannot be generalised and only certain tendencies could be determined.

\section{Data analysis}

All 60 completed questionnaires were screened by the researcher to clarify vague or inconsistent response 
information and to identify and collate the "other" responses provided. Questions on the awareness of food-borne disease were scored as either "correct" or "incorrect". "Not sure" or "don't know" awareness responses were scored as incorrect. The SPSS (Statistical Package for Social Sciences) for Windows was used for the statistical analysis of the data. Frequency results were obtained for the response categories of the questions that addressed the adherence to the food-borne disease guidelines and biographical information. The chi-squared test was applied to determine whether the aspects related to food safety awareness were associated with the related selfreported food safety behaviour. The level of significance used was $p=0,05$ or 0,001 .

\section{RESULTS AND DISCUSSION}

\section{Sample and biographic description of the respon-} dents

Sixty black female students aged between 18 and 24 years voluntarily participated in the study. The 60 students represented $7,4 \%$ of the female self-catering residence population. Slightly more than half of the respondents $(53,3 \% ; n=32)$ indicated that they were registered for the first year, $28,3 \%(n=17)$ for the second year and $18,3 \%(n=11)$ for the third year of study at the CPUT: Cape Town campus. More than a third of these respondents $(38,3 \% ; n=23)$ indicated that they were studying a course that fell under the Faculty of Management, $23,3 \%(n=14)$ were studying in the Faculty of Applied Sciences, $18,3 \%(n=11)$ in the Faculty of Business Informatics, $11,7 \%(n=7)$ in the Faculty of the Built Environment and Design and 8,3\% $(n=5)$ in the Faculty of Engineering. None indicated that they were studying a course that fell under the Faculty of Education. The campuses of the Faculty of Education are situated in Wellington and Mowbray and the residences situated in these areas had mealprovision facilities at the time that the study was conducted. Less than a third of the respondents $(28,3 \% ; n=17)$ indicated that they received information on bacterial food-borne disease, either at school or as part of a subject such as microbiology, environmental studies or food science in the course that they were studying.

\section{Food preparation practices associated with bacte- rial food-borne disease}

Purchasing All the respondents $(n=60)$ reported that they purchased ingredients for food preparation at supermarkets, while $11,7 \%(n=7)$ reported purchasing ingredients and $6,7 \% \quad(n=4)$ reported purchasing ready-to-eat food items from street vendors. Van Eeden and Gericke (1996) indicated similar purchasing practices. In their study conducted in Pretoria, the majority $(73,2 \%)$ of the urban black female students indicated regularly shopping at a supermarket, while only $6,3 \%$ indicated purchasing food items from street vendors. In contrast, in a study conducted by OpareObisaw (1998) at the University of Ghana, $86 \%$ of the respondents regularly purchased cooked meals and snacks from street vendors.
Purchasing characteristics that would decrease the risk of bacterial food-borne disease, were mentioned by half of the respondents, as $50 \%(n=30)$ reported checking for freshness of produce when purchasing food and $48,3 \% \quad(n=29)$ reported using the sell-by date. A small number $(11,7 \% ; n=7)$ indicated checking the packaging of food items. However, the majority $(73,3 \% ; n=44)$ reported that they looked at price when purchasing food items. A possible reason for this may be the available funds of students. Other characteristics reported by the respondents included brand $(53,3 \% ; n=32)$ and taste $(16,7 \% ; n=10)$.

Storage As indicated in Table 2, the majority of the respondents reported packing ingredients away immediately on arrival at the residence after shopping, and all the respondents reported storing perishable food items in the refrigerator. Similar results were obtained in a survey conducted among Sainsbury customers in the UK where the majority (84\%) of the shoppers questioned said that they quickly unpacked and stored bought food items on returning home. They also indicated an awareness of the need to store perishable food items in the refrigerator (Spriegel, 1991).

However, less in line with recommendations was the fact that only approximately half of the respondents (see Table 2) reported that they usually had sufficient space in the refrigerator for storing food. An overloaded refrigerator impairs air circulation that keeps food cold and it can also result in poor stock rotation (Eley, 1992). Only a small number of the respondents reported using the expiry date as a guideline for determining the storage time of perishable food items (see Table 2). Expiry dates are better indications of the safety of perishable food items compared with a specific storage period. Food products may no longer be fresh on purchasing if sufficient control regarding the discarding of stock past its sell-by date is not implemented in the retail store. Keeping food items such as milk, processed meats and cheese until they show signs of decay does not constitute a safe practice as processes such as pasteurisation may kill spoilage bacteria and not affect heat-resistant bacterial spores. If these food items are handled incorrectly, e.g. left at room temperature for extended periods of time, spores may proliferate. Food items may thus appear safe as no spoilage is visible, but if consumed may cause bacterial food-borne disease (Jones, 1992:108).

As indicated in Table 2, approximately one-third of the respondents reported usually storing raw meat or chicken in the refrigerator, with a third of these respondents reported storing it on the bottom shelf. An even lower number reported storing these food items in a container with a lid. Similar results on the specific storage site of raw meat, fish and poultry in the refrigerator were indicated in studies conducted by Spriegel (1991) in the UK, Jay et al (1999a) in Australia and Li-Cohen and Bruhn (2002) in the USA.

The majority of the respondents reported safe handling of frozen food items as they indicated that they 
TABLE 2: $\quad$ STORAGE PRACTICES OF RESPONDENTS $(\mathrm{N}=60)$

\begin{tabular}{|c|c|c|}
\hline \multirow{2}{*}{ Storage practice } & \multicolumn{2}{|c|}{ Respondents } \\
\hline & $\mathbf{N}$ & $\%$ \\
\hline $\begin{array}{l}\text { Pack purchased ingredients away } \\
\text { immediately }\end{array}$ & 53 & 88,3 \\
\hline Store perishables in refrigerator & 60 & 100,0 \\
\hline \multicolumn{3}{|l|}{ Space in refrigerator } \\
\hline Usually sufficient & 34 & 56,7 \\
\hline Sometimes sufficient & 8 & 13,3 \\
\hline Insufficient & 18 & 30 \\
\hline \multicolumn{3}{|l|}{ Storage time of perishable food items } \\
\hline Keep for a limited time & 44 & 73,3 \\
\hline Keep until the expiry date & 5 & 8,3 \\
\hline Keep until signs of decay & 8 & 13,3 \\
\hline Consume on day of purchase & 3 & 5,0 \\
\hline \multicolumn{3}{|l|}{ Storing raw meat/chicken $\left(n^{*}=59\right)$} \\
\hline In refrigerator & 5 & 8,5 \\
\hline In refrigerator and/or freezer & 13 & 22,0 \\
\hline Only in freezer & 41 & 69,5 \\
\hline \multicolumn{3}{|l|}{ Storing raw meat/chicken in refrigerator $*=18$ ) } \\
\hline On bottom shelf & 6 & 33,3 \\
\hline Top/middle shelf or no particular place & 12 & 66,7 \\
\hline \multicolumn{3}{|c|}{ Storing raw meat/chicken in refrigerator in container with lid $\left(n^{*}=18\right)$} \\
\hline Usually & 4 & 22,2 \\
\hline Not in container with lid & 14 & 77,8 \\
\hline \multicolumn{3}{|l|}{ Cooking of frozen food items $\left(n^{*}=54\right)$} \\
\hline Usually defrost food items & 38 & 70,3 \\
\hline Sometimes defrost food items & 11 & 20.3 \\
\hline Cook food items from frozen & 5 & 9,2 \\
\hline \multicolumn{3}{|l|}{ Method of defrosting $(n *=49)$} \\
\hline Microwave oven & 37 & 75,5 \\
\hline Refrigerator & 3 & 6,1 \\
\hline Kitchen counter & 6 & 12,2 \\
\hline Warm water & 3 & 6,1 \\
\hline
\end{tabular}

$\mathrm{n}^{\star}=$ number of respondents in group/sub-group applying practice

usually defrosted frozen meat or chicken before cooking, using either a microwave oven or the refrigerator (see Table 2). A larger percentage of the respondents used a correct method for defrosting compared with other studies. Meer and Misner (2000) reported that only $53 \%$ of the respondents indicated using a correct method for defrosting raw animal food products in a study conducted in the USA. Twenty-one per cent of their respondents indicated placing food products on a counter to defrost, while $41 \%$ indicated that they used the refrigerator, and $12 \%$ indicated that they used a microwave oven. The high percentage of respondents who reported using a microwave oven in this study could be contributed to the fact that all the kitchenettes in the self-catering residences were equipped with microwave ovens.

\section{Preparation}

Personal hygiene during preparation As indicated in Table 3 the majority of the respondents reported that they usually washed their hands before starting food preparation and after handling raw meat or chicken. A smaller number reported that they sometimes washed their hands before starting food prepa- ration and after handling raw meat or chicken. In studies conducted by Altekruse et al (1996), Yang et al (1998) and Shiferaw et al (2000), $87 \%$ to $92 \%$ of the respondents also indicated that they always or usually washed their hands before handling food, and $62 \%$ to $100 \%$ that they also always or usually washed their hands after handling raw meat or poultry.

Although a large percentage of respondents reported that they usually washed their hands, the number that indicated that they followed the correct procedure of using soap and water for lathering and rinsing (Bennion \& Scheule, 2004:62) was low (see Table 3). Less than one-third of these respondents indicated using soap and water for washing their hands before starting food preparation and an even lower number reported using soap and water after handling raw poultry or meat. More than half of the respondents who reported washing their hands indicated rinsing as the manner in which they washed their hands prior to food preparation and after handling raw meat or poultry. According to the USA Department of Agriculture (USDA), consumers may think that they have washed their hands, but in reality they have only rinsed them (Hunter, 2000). More in line with bacterial food-borne 
TABLE 3: $\quad$ PERSONAL AND GENERAL HYGIENE PRACTICES OF RESPONDENTS (N=60)

\begin{tabular}{|c|c|c|}
\hline Personal and general hygiene practices & Resp & dents \\
\hline Personal hygiene & $\mathbf{N}$ & $\%$ \\
\hline Before starting food preparation & & \\
\hline Wash hands & & \\
\hline Usually & 45 & 75,0 \\
\hline Sometimes & 15 & 25,0 \\
\hline Manner of washing hands & & \\
\hline Using soap and water & 18 & 30,0 \\
\hline Rinsing with water only & 42 & 70,0 \\
\hline Manner of drying hands & & \\
\hline Using paper or hand towel & 1 & 1,7 \\
\hline Using kitchen or drying cloth & 54 & 90,0 \\
\hline Not dried & 5 & 8,3 \\
\hline After handling raw meat or poultry & & \\
\hline Wash hands & & \\
\hline Usually & 45 & 75,0 \\
\hline Sometimes & 8 & 13,3 \\
\hline Do not wash & 7 & 11,7 \\
\hline Manner of washing hands $\left(n^{\star}=53\right)$ & & \\
\hline Using soap and water & 11 & 20,8 \\
\hline Rinsing with water only & 42 & 79,2 \\
\hline Manner of drying hands $(n *=53)$ & & \\
\hline Using paper or hand towel & 0 & 0,0 \\
\hline Using kitchen or drying cloth & 50 & 94,3 \\
\hline Not dried & 3 & 5,7 \\
\hline General hygiene & & \\
\hline Washing fresh produce & & \\
\hline Usually & 43 & 71,7 \\
\hline Sometimes & 13 & 21,7 \\
\hline Not washing & 4 & 6,7 \\
\hline Using same knife for raw and ready-to-e & & \\
\hline Usually & 33 & 55,0 \\
\hline Sometimes & 4 & 6,7 \\
\hline Not using & 23 & 38,3 \\
\hline Treatment of knife in between use of raw & & \\
\hline Washing with soap and water & 5 & 13,6 \\
\hline Rinsing with water & 30 & 81,0 \\
\hline Wiping & 2 & 5,4 \\
\hline Using the same plate/chopping board fol & & \\
\hline Usually & 21 & 35,0 \\
\hline Sometimes & 5 & 8,3 \\
\hline Not using & 34 & 56,7 \\
\hline $\begin{array}{l}\text { Treatment of plate/chopping board in be } \\
\left(n^{*}=26\right)\end{array}$ & & \\
\hline Washing with soap and water & 13 & 50,0 \\
\hline Rinsing with water & 12 & 46,2 \\
\hline Wiping & 1 & 3,8 \\
\hline Using same cloth for wiping raw food ite & & \\
\hline Usually & 29 & 48,3 \\
\hline Sometimes & 6 & 10,0 \\
\hline Not using & 25 & 41,7 \\
\hline
\end{tabular}

$\mathrm{n}^{\star}=$ number of respondents in group/sub-group applying the practice 
disease prevention guidelines are the results cited by Redmond and Griffith (2003) from surveys conducted in the UK by the Department of Health and Social Sciences and Northern Ireland Health and Social Services Board in 1998, the Food and Drink Federation in 1996 and the Food Safety Authority of Ireland in 1998. In these surveys, $87 \%$ to $92 \%$ of the respondents indicated that they always or usually washed their hands with soap and water before handling food.

Hands should be dried after washing using a clean, unused hand towel or paper towel (Bennion \& Scheule, 2004:62). However, only one of the respondents reported using either a paper towel or hand towel for drying her hands after washing, before the commencement of food preparation (see Table 3). The rest of the respondents all reported following the incorrect behaviour; that is either using a kitchen or drying cloth to dry their hands or not drying their hands.

\section{General hygiene during preparation The Food} Safety and Inspection Service (Does washing food promote safety?, 1999) recommends that fresh produce should be washed under cold running tap water before preparation or consumption to reduce or remove micro-organisms. As seen in Table 3 the majority of the respondents reported that they usually washed fruit and vegetables before eating. In a national USA mail survey conducted by Li-Cohen and Bruhn (2002) most of the respondents also indicated washing fresh produce, while only $6,7 \%$ indicated that they seldom or never washed fresh produce.

Cross-contamination can be avoided if utensils or equipment is washed with soap and water in between using it for raw and ready-to-eat food items. As seen in Table 3 more than half of the respondents reported usually using the same knife for slicing raw and readyto-eat food items. However, only a small number of these respondents reported washing the knife with soap and water in between uses. While less than half of the respondents reported usually using the same plate/chopping board for raw and ready-to-eat food items, half of them reported washing it with soap and water in between use. Less than half of the respondents also reported using the same cloth for wiping raw food items and/or surfaces and to clean or dry dishes.

These results indicate a great degree of crosscontamination as only a small percentage of the respondents reported that they would clean the knife in between using it for raw and ready-to-eat food items. More encouraging results were reported by Jay et al (1999a), Li-Cohen and Bruhn (2002) and Klontz et al (1995). In the study conducted by Jay et al (1999a), $76 \%$ of the respondents indicated that they would use the same utensil for cutting raw meat and ready-to-eat food items, but $46 \%$ indicated that they would wash the utensil with detergent and hot water in between uses. Li-Cohen and Bruhn (2002) found that $97 \%$ of the respondents indicated that they always washed their cutting surfaces after contact with meat, poultry or fish, and $86 \%$ indicated that they always cleaned the cutting surface after cutting fruit and vegetables. Klontz et al (1995) reported that $25 \%$ of the respondents in a telephone survey conducted in the USA said that they would use the same cutting board again without cleaning it with soap or bleach after cutting raw meat or chicken. Jay et al (1999a) reported that only $18 \%$ of the respondents in an Australian study indicated that they would use the same cloth for drying dishes and for drying hands.

Cooking Foods such as poultry, eggs, minced beef and seafood should be cooked to specified temperatures to kill micro-organisms associated with bacterial food-borne disease (Bennion \& Scheule, 2004:63). The majority of the respondents reported that they cooked or liked high-risk food items to be cooked thoroughly, as $86,7 \%(n=52)$ cooked chicken, or liked it to be cooked, to the well-done stage and $76,7 \%(n=46)$ cooked burger patties, or liked it to be cooked, to the well-done stage. Ninety-five per cent $(n=57)$ reported not consuming raw fish and $85 \%(n=51)$ reported not consuming dishes containing raw eggs. Similarly, Shiferaw et al (2000) and Yang et al (1998) found in multistate surveys in the USA that only a small percentage of respondents $(1,5 \%$ to $8 \%)$ reported eating raw shellfish. In contrast Altekruse et al (1999) and Klontz et al (1995) found that $50 \%$ to $53 \%$ of the respondents, in studies conducted in the USA, indicated that they ate undercooked eggs and Shiferaw et al (2000) and Yang et al (1998) respectively found that 30\% and $19,7 \%$ of their respondents respectively indicated that they preferred "pink" burger patties. In the study of Yang et al (1998) the number of respondents, in the age group 18 to 29 years, who ate "pink" meat patties increased to $21,8 \%$.

Handling left-over food As indicated in Table 4 approximately half of the respondents indicated usually or sometimes cooking food in advance of consumption. The majority of them reported storing the food prepared in advance in the refrigerator, but also reported leaving the food to reach room temperature, after cooking it, before placing it in the refrigerator. Similarly Jay et al (1999a) reported that $85 \%$ of the respondents in their telephone survey admitted that they allowed cooked food to cool to room temperature before refrigerating it.

Regarding the storage and reheating of left-over food, the majority of the respondents reported storing it in the refrigerator, in a container with a lid, for three days or less. The majority of respondents also reported that they would not reheat left-over food more than once. However, none of the respondents reported heating left-over food items or food prepared in advance to safe temperatures. Jay et al (1999a) reported that $69 \%$ of the respondents thought it was very important not to reheat food more than once. Reheating food items more than once is not necessarily a dangerous microbiological practice. However, if it is linked to leaving food at room temperature before refrigeration, it may mean that many consumers allow their left-over food items to be at unsafe temperatures for time periods that are cumulatively dangerous. 
TABLE 4:

COOKING FOOD IN ADVANCE AND LEFT-OVER FOOD HANDLING PRACTICES OF RESPONDENTS ( $\mathrm{N}=60)$

\begin{tabular}{|c|c|c|}
\hline Cooking food in advance and handling left-over food & \multicolumn{2}{|c|}{ Respondents } \\
\hline Cooking food in advance of consumption & & \\
\hline Usually & 24 & 40,0 \\
\hline Sometimes & 8 & 13,3 \\
\hline Not cooking in advance & 28 & 46,7 \\
\hline \multicolumn{3}{|l|}{ Storing food cooked in advance $(n *=32)$} \\
\hline In refrigerator & 26 & 81,3 \\
\hline In cupboard or on kitchen counter or stove & 6 & 18,8 \\
\hline \multicolumn{3}{|c|}{ Leaving food to reach room temperature before refrigerating $\left(n^{*}=26\right)$} \\
\hline Usually & 21 & 80,8 \\
\hline Sometimes & 4 & 15,4 \\
\hline No & 1 & 3,8 \\
\hline \multicolumn{3}{|l|}{ Handling left-over food } \\
\hline \multicolumn{3}{|l|}{ Storing left-over food } \\
\hline In refrigerator & 49 & 81,7 \\
\hline In cupboard or on kitchen counter or stove & 11 & 18,3 \\
\hline \multicolumn{3}{|l|}{ Storing left-over food in the refrigerator $\left(n^{*}=49\right)$} \\
\hline In container with lid & 48 & 97,9 \\
\hline Not in container with lid & 1 & 2,1 \\
\hline \multicolumn{3}{|l|}{ Storage time of left-over food in refrigerator $(n *=49)$ : } \\
\hline 3 days or less & 44 & 89,7 \\
\hline 4 days or more & 5 & 10,3 \\
\hline \multicolumn{3}{|l|}{ Reheating food prepared in advance and left-over food } \\
\hline \multicolumn{3}{|l|}{ Stage of reheating } \\
\hline Until boiling hot & 0 & 0,0 \\
\hline Until hot & 31 & 51,7 \\
\hline Until warm & 29 & 48,3 \\
\hline \multicolumn{3}{|l|}{ Reheating it more than once } \\
\hline Usually & 10 & 16,7 \\
\hline Sometimes & 2 & 3,3 \\
\hline No & 48 & 80,0 \\
\hline
\end{tabular}

$\mathrm{n}^{\star}=$ number of respondents in the group/sub-group applying the practice

Food-borne disease awareness related to food practices associated with decreased risk of bacterial food-borne disease

\section{Awareness of the causes of food-borne disease}

Awareness of the causes of food-borne disease was low as less than half of the respondents mentioned any of the causes associated with food-borne disease. The cause that was mentioned by most of the respondents was food items that were stored for too long However, only 8 respondents $(13,3 \%)$ indicated that they would store perishable food items until its showed signs of decay. Less than half of the respondents indicated bacteria as an organism that is linked to food-borne disease. Table 5 indicates the causes of food-borne disease as indicated by the respondents.

A far higher awareness of the causes of microbial food-borne disease was found in a telephone survey conducted by Jay et al (1999a). In the Australian survey, $88 \%$ of the respondents contributed food-borne disease to the incorrect storage of food items, $80 \%$ to bacteria, $79 \%$ to consumption of food items past their use-by date and $74 \%$ to incorrect cooking. Similar to this study, a small percentage of the respondents $(2,1 \%)$ also indicated that they did not know the causes of food-borne disease.

Awareness of specific bacteria associated with foodborne disease was also limited, as a large percentage of respondents could not name any bacteria associated with bacterial food-borne disease. The majority of respondents that indicated the name of a bacterium mentioned Salmonella. Table 6 indicates the number and percentage of respondents that mentioned each type of bacteria.

Results from other studies indicated a higher level of 
TABLE 5:

NUMBER AND PERCENTAGE OF RESPONDENTS $(\mathrm{N}=60)$ WHO INDICATED EACH OF THE CAUSES OF FOOD-BORNE DISEASE

\begin{tabular}{|c|c|c|}
\hline Causes of microbial food-borne disease & \multicolumn{2}{|c|}{ Respondents } \\
\hline Causes relating to food practices & $\mathbf{n}$ & $\%$ \\
\hline \multicolumn{3}{|l|}{ Purchasing } \\
\hline Contaminated food items & 23 & 38,3 \\
\hline \multicolumn{3}{|l|}{ Storage } \\
\hline Food stored for too long & 28 & 46,7 \\
\hline \multicolumn{3}{|l|}{ Preparation } \\
\hline \multicolumn{3}{|l|}{ Personal hygiene } \\
\hline Hands not washed & 17 & 28,3 \\
\hline Poor hygiene practices & 20 & 33,3 \\
\hline \multicolumn{3}{|l|}{ General hygiene } \\
\hline Dirty equipment and utensils & 22 & 36,7 \\
\hline Cross-contamination between raw and cooked food & 13 & 21,7 \\
\hline Contact with animals and flies & 11 & 18,3 \\
\hline \multicolumn{3}{|l|}{ Cooking } \\
\hline Food items not cooked to well done & 9 & 15,0 \\
\hline Food items held at warm temperatures for too long & 20 & 33,3 \\
\hline Food not cooled quickly after cooking & 1 & 1,7 \\
\hline \multicolumn{3}{|l|}{ Handling left-over food } \\
\hline Leftovers not reheated to boiling point & 7 & 11,7 \\
\hline \multicolumn{3}{|l|}{ Organisms causing microbial food-borne disease } \\
\hline Bacteria & 27 & 45,0 \\
\hline Viruses & 13 & 21,7 \\
\hline Other micro-organisms, e.g., mould & 13 & 21,7 \\
\hline Don't know & 3 & 5,0 \\
\hline
\end{tabular}

consumer awareness regarding food-borne disease causing bacteria. In the study conducted by Jay et al (1999a), 96\% of the respondents indicated that they had heard of Salmonella. Similarly, in a study conducted by Woodburn and Raab (1997) in the USA, $99 \%$ of the respondents recognised Salmonella as a problem in food. And $88 \%$ could name appropriate foods at high risk of Salmonella contamination. Poor results were also obtained with regard to the question on the association between Salmonella food-borne disease and specific food items or food preparation practices. Only 15 respondents $(25,0 \%)$ indicated an association between Salmonella and poultry and only 3 respondents $(5,0 \%)$ indicated that contamination might occur when raw poultry came into contact with ready-to-eat food items. None of the respondents indicated that inadequate cooking could be associated with Salmonella food-borne disease. Results from other studies again show a greater awareness of bacterial food-borne disease. Williamson et al (1992) reported that $74 \%$ of the respondents in a mail survey associated Salmonella with raw poultry and eggs.

Only 26 respondents $(43,3 \%)$ could indicate the meaning of the term "cross-contamination" $20(33,3 \%)$ of whom indicated that they understood it to be when raw and ready-to-eat foods were in contact with each other, while four $(6,6 \%)$ referred to the preparation of food on a contaminated surface and two $(3,3 \%)$ men- tioned using the same knife for raw and ready-to-eat foods.

Food practices associated with decreased risk of bacterial food-borne disease The 18 respondents (30\%) who were aware of the association between Salmonella and poultry $(n=15)$ and that raw poultry may cause contamination $(n=3)$ were not more likely to report following the corresponding Salmonella foodborne disease prevention guidelines than those who were not aware of the association. Only 2 of the 13 respondents who reported washing a plate/chopping board with soap and water in between using it for raw and ready-to-eat food items and only 2 of the 11 respondents who reported washing hands with soap and water after handling raw poultry indicated the association between Salmonella and poultry. In addition, only 1 of the 5 respondents who reported washing a knife with soap and water in between using it for raw and ready-to-eat food items indicated the association mentioned above.

Respondents who were able to describe crosscontamination ( $n=26 ; 43,3 \%$ ) were also not more likely to report using the corresponding cross-contamination prevention practices. Only 6 of the 13 respondents who reported washing a plate/chopping board with soap and water in between using it for raw and readyto-eat food items and only 5 of the 11 respondents 
TABLE 6: NUMBER AND PERCENTAGE OF RESPONDENTS ( $\mathrm{N}=60)$ WHO INDICATED SPECIFIC BACTERIA ASSOCIATED WITH FOODBORNE DISEASE

\begin{tabular}{|l|c|c|}
\hline \multirow{2}{*}{\multicolumn{1}{c|}{ Bacteria }} & \multicolumn{2}{c|}{ Respondents } \\
\cline { 2 - 3 } & $\mathbf{n}$ & $\%$ \\
\hline Salmonella & 25 & 41.7 \\
\hline Staphylococcus aureus & 7 & 11.7 \\
\hline Clostridium botulinium & 6 & 10.0 \\
\hline Bacillus cereus & 5 & 8.3 \\
\hline Clostridium perfringens & 4 & 6.7 \\
\hline Escherichia coli & 4 & 6.7 \\
\hline Shingella & 3 & 5.0 \\
\hline Camplyobacter Jejuni & 1 & 1.7 \\
\hline Don't know & 27 & 45.0 \\
\hline
\end{tabular}

who reported washing hands with soap and water after handling raw poultry described crosscontamination as contact between contaminated food or equipment and ready-to-eat food items. In addition 4 of the 6 respondents who reported storing meat or chicken on the bottom shelf of the refrigerator and only 1 of the 5 respondents who reported washing a knife with soap and water in between using it for raw and ready-to-eat food items explained crosscontamination satisfactorily. None of these associations were significant.

The finding that an awareness of bacterial food-borne disease does not necessarily lead to safe food practices is supported by studies conducted by Mclntosh et al (1994), Altekruse et al (1996) and Woodburn and Raab (1997). The disparity between awareness and practices may be due to a lack of food preparation experience. Altekruse et al (1996) based this assumption on the fact that although the knowledge of specific groups of consumers, such as young adults and occasional food preparers, was similar to that of the overall sample, they had lower rates of self-reported adherence to bacterial food-borne disease prevention practices. In this study 17 respondents $(28,3 \%)$ indicated that they had been exposed to information on bacterial food-borne disease, either at school or as part of a subject at the CPUT. However, they may not practically apply the theoretical principles of bacterial foodborne disease prevention in their own food preparation practices.

In contrast, although only 18 respondents (30\%) were aware of the association between poultry and Salmonella, 52 respondents $(86,7 \%)$ reported cooking chicken or liking it to be cooked to the well-done stage. However, this may be due to personal taste rather than an awareness of the risk associated with the consumption of undercooked poultry.

\section{CONCLUSION AND RECOMMENDATIONS}

As only a small sample was used the results could not be generalised to the population of self-catering residential students as a whole. However, the results obtained do provide a description of the current food safety practices and dietary intake of the sample studied. This study indicated that although female students in self-catering residences adhered to some bacterial food-borne disease prevention guidelines, personal and general hygiene practices were neglected. However, a return to the previous system of catered residential meals, where the purchasing and storage of food items and the preparation of meals are done according to guidelines set by the contracted catering company, is not financially viable. At present institutions of higher education are more accessible to students from previously disadvantaged backgrounds with the resultant increase in the number of students with limited financial resources.

Several studies have concluded that education regarding the prevention of food-borne disease is required if standards are to improve (Barrett et al, 1996; Ropkins \& Beck, 2000; Medeiros et al, 2001b; Gorman et al, 2002; Li-Cohen \& Bruhn, 2002). In this study, students indicated low levels of awareness regarding the causes of food-borne disease, high-risk food items and cross-contamination. Although a higher awareness of food-borne disease issues does not necessarily lead to food practices more in line with bacterial food-borne disease prevention guidelines, the results from studies conducted by Altekruse et al (1996), Meer and Misner (2000) and Lin et al (2004) indicate that a raised awareness of these issues can be a potentially useful approach to promote safer food practices.

Based on these determined behaviour tendencies it is recommended that an intervention programme aimed at improving adherence to bacterial food-borne disease prevention guidelines by female students living in self-catering residences be designed and implemented. The time spent attending tertiary institutions has been identified as one of the most influential times in students' lives, providing the perfect opportunity to instil lifelong habits (Klemmer, 2002). According to Huang et al (2003), colleges and universities can be ideal settings for interventions because students are still forming lifestyle patterns. Although all consumers would benefit from interventions aimed at improving adherence to bacterial food-borne disease prevention guidelines, results of studies conducted by Williamson et al (1992) and Woodburn and Raab (1997) indicate that these programmes should be directed towards consumers younger than 35 years of age.

This study was a once-off survey of the food practices of female students living in self-catering residences at the CPUT:Cape Town campus. Male students residing in self-catering residences were not included in this study. It is assumed that they will exhibit similar behaviour to the female students, but this assumption has not been empirically tested. A large number of students also do not live in residences, but in flats or rooms, where they are responsible for their own food provision. The facilities available to them differ from 
those provided in the residences, which may in turn affect their food practices. It is thus recommended that the food practices of male students in selfcatering residences and those of students living in flats or rooms also be investigated and that based on the results of these studies, the intervention be extended to include female and male students in selfcatering residences and all students who are responsible for their own food provision.

The Cape Peninsula University of Technology is acknowledged for providing financial assistance for this research. The authors would like to thank Mrs R Krause for statistical processing of data.

\section{REFERENCES}

ADAMS, MR \& MOSS, MO. 1995. Food microbiology. Cambridge. The Royal Society of Chemistry.

ALTEKRUSE, SF, STREET, DA, FEIN, SB \& LEVY, AS. 1996. Consumer knowledge of food-borne microbial hazards and food-handling practices. Journal of Food Protection 59(3):287-294.

ALTEKRUSE, SF, YANG, S, TIMBO, BB \& ANGULO, FJ. 1999. A multi-state survey of consumer foodhandling and food-consumption practices. American Journal of Preventative Medicine 16(3):216-221.

AZANZA, PV. 2001. Food consumption and buying patterns of students from a Philippine university fast food mall. International Journal of Food Science and Nutrition 52(6):515-520.

BABBIE, E. 1990. Survey research methods. $2^{\text {nd }}$ ed Belmont, CA. Wadsworth.

BARRETT, EB, PENNER, KP \& SHANKLIN, CW. 1996. The impact of train-the-trainer food safety education. Food Technology 50(7):89-91.

BEAN, NH \& GRIFFEN, PM. 1990. Foodborne disease outbreaks in the United States, 1973-1978: pathogens, vehicles and trends. Journal of Food Protection 53: 804-817

BENNION, M \& SCHEULE, B. 2004. Introductory foods. $12^{\text {th }}$ ed. Upper Saddled River, NJ. Pearson Education International.

BEUCHAT, LR \& RYU, JH. 1997. Produce handling and processing practices. Emerging Infectious Diseases 3(4):459-465.

BEUMER, RR \& KUSUMANINGRUM, H. 2003. Kitchen hygiene in daily life. International Biodeterioration \& Biodegradation 51(4):299-302.

BORCH, E \& ARINDER, P. 2003. Bacteriological safety issues in red meat and ready-to-eat meat products, as well as control measures. Meat Science 62 (3):381-390.

BOWLING, A. 2002. Research methods in health: investigating health and health services. $2^{\text {nd }}$ ed. Maidenhead: Open University Press.

BRINKMAN, E, DIJK, R, VAN NIEUWLAND \& BEUMER, RR. 1999. Microbiological quality of leftovers of foods from domestic environments and effect of chilled storage. In Tuijtelaars, ACJ, Samson, RA, Rombouts, FM \& Notermans, S. (Eds). 1999. Food microbiology and food safety into the next millennium: proceedings of the $17^{\text {th }}$ International Conference on Food Microbiology and Hygiene (ICFMH), Veldhoven,
The Netherlands, 13-17 September 1999. TNO. Zeist, The Netherlands.

BROWN, A. 2000. Understanding food: principles and preparation. Belmont, CA. Wadsworth-Thompson Learning.

BRYAN FL. 1988. Risks of practices, procedures and processes that lead to outbreaks of food-borne illness. Journal of Food Protection 51(8):663-673

CANADIAN FOOD INSPECTION AGENCY (CFIA). 1998. Safe food handling study. http://www.canfightbac.org/english/ccentre/highlighte.shtml Accessed 29 June 2002.

CHICKEN SAFETY TIPS. 2001. Consumer Institute of New Zealand. Available online. http:// www.consumer.org.nz/topic.html Accessed 17 July 2004.

CLAYTON, DA, GRIFFITH, CJ \& PRICE, P. 2003. An investigation of the factors underlying consumers' implementation of specific food safety practices. British Food Journal 105(7):434-453.

COLLINS, JE. 1997. Impact of changing consumer lifestyles on the emergence/re-emergence of foodborne pathogens. Emerging Infectious Diseases 3 (4):471-479.

CRAWFORD, L. \& MURANO, E. 2002. Interview with USDA \& FDA food safety leaders. Food Insight Sept/ Oct: $1 \& 6$

DE WIT, JC, BROEKHUIZEN, G \& KAMPELMACHER, EH. 1978. Kruisbesmetting bij de bereiding van diepvrieskuikens in de keuken. Voeding 39 (7):208-210.

DOES WASHING FOOD PROMOTE SAFETY? 1999. Food Safety and Inspection Service. Available online. http://www.fsis.usda.gov/OA/pubs/washing.htm_ Accessed 16 August 2003.

DOYLE, MP. 1993. Reducing food-borne disease: what are the priorities? Nutrition Reviews 51(11):345347.

ELEY, A. 1992. Food safety in the home: current microbiological perspectives. Nutrition and Food Science 92(5):8-13.

ENRIQUEZ, CE, ENRIQUEZ-GORDILLO, R, KENNEDY, DI \& GERBA, C.P. 1997. Bacteriological survey of used cellulose sponges and cotton dishcloths from domestic kitchens. Dairy, Food and Environmental Sanitation 17(1):20-24.

GORMAN, R, BLOOMFIELD, S \& ADLEY, CA. 2002. A study of cross-contamination of food-borne pathogens in the domestic kitchen in the Republic of Ireland. International Journal of Food Microbiology 76(12):143-150.

GRIFFITH, CJ \& REDMOND, E. 2001. Evaluating hygiene behavior in the domestic setting and the impact of hygiene education. Journal of Infection 43 (1):70-74

GRIFFITH, CJ \& WORSFOLD, D. 1994. Application of HACCP to food preparation practices in domestic kitchens. Food Control 5(3):200-205.

HANDLING FOOD IN THE HOME. 2000. Food Science Australia. Available online. http://www.dfst.csiro.au/handling.htm Accessed 6 May 2004.

HARRISON, WA, GRIFFITH, CJ, TENNANT, D \& PETERS, AC. 2001. Incidence of Campylobacter and Salmonella isolated from retail chicken and associated packaging in South Wales. Letters in Applied Microbi- 
ology 33(6): 450-454.

HAYSOM, I \& SHARP, K. 2004. Crosscontamination from raw chicken during meal preparation. British Food Journal 106(1):38 - 50

HUANG, TT, HARRIS, KJ, LEE, RE, NAZIR, N, BORN, W \& KAUR, H. 2003. Assessing overweight, obesity, diet and physical activity in college students. Journal of American College Health 52(2):83-86. HUNTER, BT. 2000. So, how important is hand washing? Consumers' Research Magazine, 83(4):23-27.

HUYSAMEN, GK. 1994. Methodology for the social and behavioural sciences. Halfway House. Southern Book Publishers.

JAY, LS, COMAR, D \& GOVENLOCK, LD. 1999a. A national Australian food safety telephone survey. Journal of Food Protection 62(8):921-928.

JAY, LS, COMAR, D \& GOVENLOCK, LD. 1999b. A video study of Australian domestic food-handling practices. Journal of Food Protection 62(11):1285-1296.

JONES, JM. 1992. Food safety. St Paul, MN. Eagan Press.

KLEMMER, S. 2002. Tufts research supports interdependence of healthy lifestyle behaviours. Nutrition Bulletin 27(2):97-100

KLONTZ, KC, TIMBO, B, FEIN, S \& LEVY, A. 1995. Prevalence of selected food consumption of preparing behaviors associated with increased risks of foodborne disease. Journal of Food Protection 58(8):927930.

KNABEL, SJ. (Ed.). 1995. Food-borne illness: role of home food handling practices. Food Technology 49 (4):119-131.

KUBHEKA, LC, MOSUPYE, FM \& VON HOLY, A. 2001. Microbiological survey of street-vended salad and gravy in Johannesburg city, South Africa. Food Control 12(2):127-131.

LEWIS, C. 1998. Home Cookin'. FDA Consumer 32 (1):20-21.

LI-COHEN, AE \& BRUHN, CM. 2002. Safety of consumer handling of fresh produce from the time of purchase to the plate: a comprehensive consumer survey. Journal of Food Protection 65(8):1287-1296.

LIN, CJ, JENSEN, KL \& YEN, ST. 2004. Awareness of food-borne pathogens among US consumers. Food Quality and Preference (article in press: corrected proof). Available online. http://www.sciencedirect.com/ science Accessed 2 December 2004.

MASON, EJ \& BRAMBLE, WJ. 1989. Understanding and conducting research: applications in education and the behavioral sciences. $2^{\text {nd }}$ ed. New York. McGraw-Hill.

MATTICK, KL, DURHAM, K, HENDRIX, M, SLADER, J, GRIFFITH, C, SEN, M \& HUMPHREY, T. 2003. The microbiological quality of washing-up water and the environment in domestic and commercial kitchens. Journal of Applied Microbiology 94(5):842- 847. MCINTOSH, WA, CHRISTENSEN, LB \& ACUFF, GR. 1994. Perceptions of risks of eating undercooked meat and willingness to change cooking practices. Appetite 22:83-96.

MEAD, PS, SLUTSKER, L, DIETZ, V, MCGRAIG, LF, BRESSEE, JS, SHAPIRO, C, GRIFFEN, PM \& TAUXE, RV. 1999. Food-related illness and death in the United States. Emerging Infectious Diseases 5 (5):607-625
MEDEIROS, LC, HILLERS, VN, KENDALL, PA \& MASON, A. 2001a. Food safety education: what should we be teaching consumers? Journal of Nutrition Education 33(2):108-114.

MEDEIROS, LC, KENDALL, P, HILLERS, V, GANG, C \& DIMASCOLA, S. 2001b. Identification and classification of consumer food-handling behaviors for food safety education. Journal of the American Dietetic Association 101(11):1326-1339.

MEER, RR \& MISNER, S. 2000. Food safety knowledge and behavior of the Expanded Food and Nutrition Program participants in Arizona. Journal of Food Protection 63(12):1725-1731.

MENSAH, P, YEBOAH-MANU, D, OWUSU-DARKO,

$K$ \& ABLORDEY, A. 2002. Street foods in Accra,

Ghana: how safe are they? Bulletin of the World

Health Organization 80(7):546-554.

MEREDITH, L, LEWIS, R \& HASLUM, M. 2001. Contributory factors to the spread of contamination in a model kitchen. British Food Journal 103(1):23-36.

MILES, S, BRAXTON, DS \& FREWER, LJ. 1999.

Public perceptions about microbiological hazards in food. British Food Journal 101(10):744-762.

MOORE, JE, WILSON, TS, WAREING, DR, HUMPHREY, TJ \& MURPHY, PG. 2002. Prevalence of thermophilic Campylobacter spp. in ready-to-eat foods and raw poultry in Northern Ireland. Journal of Food Protection 65(8): 1326-1328.

MOSUPYE, FM \& VON HOLY, A. 2000. Microbiological hazard identification and exposure assessment of street vending in Johannesburg, South Africa. International Journal of Food Microbiology 61(2/3):137-145 NEL, JH \& STEYN, NP. 2001. Report on South African food consumption studies undertaken amongst different population groups (1983-2000): average intakes of foods most commonly consumed. Available online. http://www.mrc.ac.za/chronic/foodstudy_ Accessed 29 November 2002.

OPARE-OBISAW, G. 1998. Students' patronage and views on the operations and services of food vendors. Journal of Consumer Studies and Home Economics 22(3):139-146.

PATRICK, DR, FINDON, G \& MILLER, TE. 1997. Residual moisture determines the level of touch contact associated bacterial transfer following hand washing. Epidemiology and Infection 119:319-325.

PELCZAR, MP, CHAN, ECS \& KRIEG, NR. 1993. Microbiology: concepts and applications. New York. McGraw-Hill.

RALSTON, K, STARKE, Y, BRENT, P \& RIGGINS, T. 2000. Awareness of risks: changing how hamburgers are cooked. Food Review 23(2):44-46.

REDMOND, EC \& GRIFFITH, CJ. 2003. Consumer food handling in the home: a review of food safety studies. Journal of Food Protection 66(1):130-161. RESIDENCE FACILITIES. 2003. Cape Technikon.

Available online. http://www.ctech.ac.za/serv/res/

facilities.html Accessed 12 August 2003.

ROBERTS, D. 1990. Sources of infection: food. The Lancet 336(8719): 859-861.

ROPKINS, K \& BECK, AJ. 2000. HACCP in the home: a framework for improving awareness of hygiene and safe food handling with respect to chemical risk. Trends in Food Science and Technology 11:105114. 
ROSSET, R. 2001. Croissance microbienne et froid. Étude du cas particulier de Listeria monocytogenes. Bulletin de l'Academie Nationale de Medicine 185 (2):287-289.

SCOTT, E \& BLOOMFIELD, SF. 1990. The survival and transfer of microbial contamination via cloths, hands and utensils. Journal of Applied Bacteriology 68:271-278.

SHARP, K \& WALKER, H. 2003. A microbiological survey of communal kitchens used by undergraduate students. International Journal of Consumer Studies 27(1):11-16.

SHIFERAW, B, YANG, S, CIESLAK, P, VUGIA, D, MARCUS, R, KOEHLER, J, DENEEN, V \& ANGULO, F. 2000. Prevalence of high-risk food consumption and food-handling practices among adults: a multistate survey, 1996 to 1997. Journal of Food Protection 63(11):1538-1543.

SIDLEY, P. 1995. The germ of a food problem. Available online. http://www.mweblibrary.com/nxt/ gateway.dIl/ Accessed 4 March 2003.

SIMPSON, S. 1993. Domestic food safety and hygiene: educating the consumer. Nutrition and Food Science 93(2):4-8.

SOUTH AFRICA. DEPARTMENT OF HEALTH. 1977. Regulations under the Health Act (Act No. 63 of 1977). Notice 176 of 1996. Government Gazette (16969):49.

SPRIEGEL, G. 1991. Food safety in the home. Nutrition and Food Science: 14-15, November/December. STUDENT STATISTICS. 2003. Cape Technikon Bulletin: 3, 16 May.

THE BIG THAW. SAFE DEFROSTING METHODS FOR CONSUMERS. 2003. Food Safety and Inspection Service. Available online. http://www.fsis.usda.gov/OA/pubs/bigthaw.htm Accessed 6 May 2004. UNKLESBAY, N, SNEED, J \& TOMA, R. 1998. College students' attitudes, practices, and knowledge of food safety. Journal of Food Protection 61(9): 11751180.

VAN EEDEN, TS \& GERICKE, GJ. 1996. Effect of acculturation on habitual food intake and dietary patterns of rural and urban black home economics stu- dents. The SA Journal of Food Science and Nutrition 8(3):85-94.

VAN NIEROP, W, DUSE, AG, MARAIS, E, AITHMA, $\mathrm{N}$, THOTHOBOLO, N, KASSEL, M, STEWART, R, POTGIETER, A, FERNANDES, B, GALPIN, JS \& BLOOMFIELD, SF. 2005. Contamination of chicken carcasses in Gauteng, South Africa, by Salmonella, Listeria monocytogenes and campylobacter. International Journal of Food Microbiology 99(1):1-6

WILLIAMSON, DM, GRAVANI, RB \& LAWLESS, HT. 1992. Correlating food safety knowledge with home food-preparation practices. Food Technology 46 (5):94-100.

WOODBURN, MJ \& RAAB, CA. 1997. Household food preparers' food-safety knowledge and practices following widely publicized outbreaks of food-borne illness. Journal of Food Protection 60(9):1105-1109.

WORSFOLD, D. 1995. Recipe for food safety. Nutrition and Food Science 96(6):22-25.

WORSFOLD, D \& GRIFFITH, CJ. 1995. A generic model for evaluating consumer food safety behaviour. Food Control 6(6):357-363.

WORSFOLD, D \& GRIFFITH, CJ. 1997a. Assessment of the standard of consumer food safety behaviour. Journal of Food Protection 60(4):399-406. WORSFOLD, D \& GRIFFITH, CJ. 1997b. Food safety behaviour in the home. British Food Journal 99(3):97-104.

YANG, S, LEFT, MG, MCTAGUE, D, HORVATH, KA, JACKSON-THOMPSON, J, MURAYI, T, BOESELAGER, GK, MELNIK, TA, GILDEMASTER, MC, RIDINGS, DL, ALTEKRUSE, SF \& ANGULO, FJ. 1998. Multistate surveillance for food-handling, preparation, and consumption behaviors associated with foodborne diseases: 1995 and 1996. Morbidity and Mortality Weekly Report 47(4):S33-S57.

ZHAO, C, GE, B, DE VILLENA, J, SUDLER, R, YEH, E, ZHAO, S, WHITE, DG, WAGNER, D \& MENG, J. 2001. Prevalence of Campylobacter, spp, Escherichia coli and Salmonella serovars in retail chicken, turkey, pork, and beef from the Greater Washington, DC area. Applied and Environmental Microbiology 67(12):54315436. 